\title{
Pendidikan dan Pelatihan Persiapan Perkawinan bagi Calon Pasangan Suami Istri di Paroki St. Yosef Onekore Ende
}

\author{
John M. Balan 1*, Baltasar Taruma Djata², Aurelius Fredimento ${ }^{3}$ \\ 1,2,3 Universitas Flores, Ende, Indonesia \\ *Corresponding Author: paterjohn@gmail.com
}

\begin{abstract}
Info Artikel
Diterima: 27/01/2022

Direvisi: 29/01/2022

Disetujui: 04/02/2022

Abstract. Marriage preparation education and training for prospective married couples also have been known in Indonesia as marriage preparation training courses (KPP). Like the other parishes in every diocese all over the world, St. Joseph Parish of Onekore Ende which belong to the vicariate pastoral ministry area of Ende, and the Archdiocese of Ende cares and pays more attention to the needs of parish community members who are planning to build a family up for living together as husband and wife. So, responding to the needs of these prospective couples and based on the pastoral activity planning that has been designed in an annual plenary pastoral assembly, the Parish Pastoral Council, through the Family Pastoral Section of the Parish, carries out an educational and training program for the premarital marriage preparation activities under the coordination of the Parish Pastor and his fellow co-pastor. The facilitators use the acronym term PMPET in this article. PMPET is shortened from Premarital Marriage Preparation Education and Training. The purpose is to know whether PMPET as an approach and model be able to enhance the knowledge and skill of the participants about the nature of marriage which is discussed from various perspectives or points of view.
\end{abstract}

Keywords: Education \& Training, Effectivity \& Efficiency, Marriage Preparation, Premarital

Abstrak. Pendidikan dan pelatihan persiapan perkawinan bagi pasangan calon nikah lazimnya disebut juga kursus persiapan perkawinan (KPP). Sebagaimana di paroki-paroki lain di setiap keuskupan di Indonesia, Paroki St. Yoseph Onekore Ende, yang berada wilayah reksa pastoral Kevikepan Ende, dan Keuskupan Agung Ende, juga peduli dan memperhatikan akan kebutuhan warga umatnya yang berencana untuk membangun keluarga untuk hidup bersama sebagai suami-isteri. Menanggapi kebutuhan calon-calon pasangan ini dan berdasarkan rencana kegiatan pastoral yang telah dirancang-bangun dalam rapat pleno, Dewan Pastoral Paroki, melalui seksi Pastoral Keluarga Paroki, melaksanakan kegiatan pendidikan dan pelatihan di bawah koordinasi Pastor Paroki dan Pastor rekannya. Para fasilitator menggunakan singkat istilah PMPET. Tujuannya adalah untuk mengetahui apakah PMPET sebagai sebuah pendekatan dapat meningkatkan pengetahuan dan keterampilan peserta akan hakikat perkawinan yang dibahas dari berbagai sudut pandang.

Kata Kunci: Pendidikan dan latihan, efektivitas, efisiensi, persiapan perkawinan, pranikah.

How to Cite: Balan, J.M., Djata, B. T., \& Fredimento, A. (2022). Pendidikan dan Pelatihan Persiapan Perkawinan bagi Calon Pasangan Suami Istri di Paroki St. Yosef Onekore Ende. Prima Abdika: Jurnal Pengabdian Masyarakat, 2(1), 38-54. https://doi.org/10.37478/abdika.v2i1.1649 licensed under a Creative Commons Attribution-ShareAlike 4.0 International License.

\section{Pendahuluan}

Pendidikan dan pelatihan persiapan perkawinan bagi pasangan calon nikah lazimnya disebut kursus persiapan perkawinan (KPP). Sebagaimana di paroki-paroki lain di setiap keuskupan, Paroki St. Yoseph Onekore Ende, di wilayah reksa pastoral Kevikepan Ende, dan Keuskupan Agung Ende, juga peduli dan memperhatikan akan kebutuhan warga umatnya yang berencana untuk membangun keluarga dan kehidupan bersama sebagai suami-isteri. Menanggapi kebutuhan calon-calon pasangan ini dan berdasarkan rencana kegiatan pastoral yang telah dirancang-bangun dalam rapat pleno, Dewan Pastoral Paroki, melalui seksi Pastoral Keluarga Paroki, melaksanakan kegiatan pendidikan dan pelatihan di bawah koordinasi Pastor Paroki dan Pastor rekannya. 
Aspek legal-formal yang mendukung kegiatan PKM di wilayah reksa pastoral Paroki St. Yosef Onekore adalah surat perjanjian kerja sama antara Pengurus Gereja dan Dana Papa Miskin Dewan Pastoral Paroki St. Yosef Onekore, Kevikepan Ende, Keuskupan Agung Ende dengan Program Studi PGSD Universitas Flores tentang Pendidikan dan Pelatihan Persiapan Perkawian bagi para calon pasangan suami istri. Berikutnya, surat permohonan dari Panitia Penyelenggara Pendidikan dan Pelatihan Persiapan Perkawinan Paroki St, Yosef Onekore, seksi rekruitmen tenaga fasilitator untuk mendapatkan tenaga fasilitator dari PGSD Universitas.

Tujuan yang mau dicapai dalam kegiatan pendidikan dan pelatihan persiapan perkawinan bagi calon-calon pasangan nikah di Paroki St. Yosef Onekore adalah agar mereka dapat:

a. memahami dasar dan sumber-sumber ajaran resmi gereja katolik tentang hakikat dan tujuan perkawinan katolik dari berbagai sudut pandang: Kitab Suci, Teologi, Teologi Moral Perkawinan, Moral Seksualitas, Hukum Gereja, Psikologi (Kepribadian dan Seksualitas), Komunikasi dan keterampilan berkomunikasi, Pengelolaan ekonomi rumah tangga, Kesehatan fisik dan mental, Pendidikan dalam keluarga, dan Peranan doa dalam keluarga Katolik

b. menghayati dan mengamalkan nilai-nilai sakramen perkawinan dalam kehidupan sebagai pasangan suami-isteri dan keluarga.

c. berusaha menambah dan memerluas wawasan pengetahuan dan keterampilan yang telah diperoleh dari waktu ke waktu.

d. Semakin trampil dalam mengelola konflik, mengambil keputusan yang tepat dan bertanggungjawab menurut asas-asas dan prinsip-prinsip moral Kristiani.

e. mengetahui apakah PMPET berpengaruh untuk meningkatkan pengetahuan dan keterampilan peserta akan hakikat perkawinan yang dibahas dari berbagai sudut pandang.

\section{Metode Pelaksanaan}

Pelaksanaan kegiatan PMPET Paroki St. Joseph Onekore, mengikuti mekanisme atau prosedur sebagai berikut:

a. Penjaringan dan pendaftaran calon pasangan nikah.

Mekanisme penjaringan dan pendaftaran calon peserta pendidikan dan pelatihan persiapan perkawinan, ditempuh melalui pengumumanpengumuman resmi paroki, selama beberapa minggu pada setiap perayaan Misa Kudus pada hari Minggu. Calon-calon pasangan yang telah berpacaran dan bertunangan berdasarkan tata cara budaya dan adatistiadat mendaftarkan diri di Sekretariat Paroki tanpa membatasi kuota dengan dasar pertimbangan kesiapan calon-calon pasangan nikah untuk mengikut pendidikan dan pelatihan dimaksud.

b. Syarat-syarat pendaftaran

Pasangan calon nikah yang merasa sudah siap mengikuti pendidikan dan pelatihan persiapan perkawinan difasilitasi oleh Seksi Pastoral Keluarga dan Sekretariat Paroki untuk menyiapkan diri, dengan memperhatikan syarat yang diperlukan antara lain fotocopy surat baptis bagi yang 
beragama Katolik dan calon beda gereja, Akta Kelahiran,Kartu Keluarga, Pasfoto warna ukuran 3×4, 3 lembar untuk masing-masing calon, Surat rekomendasi Pastor Paroki bagi calon pasangan yang berasal dari parokiparoki lain.

c. Pelaksanaan Kegiatan

Waktu : 20 - 23 September 2021.

Peserta : 26 calon pasangan nikah (52 orang)

d. Materi PMPET :

Pendidikan Iman dan Peranan Doa dalam Keluarga; Kesehatan Jasmani, dan Keluarga Berencana; Manajemen Ekonomi Rumah Tangga; Psikologi Kesehatan Mental Pria dan Wanita; Komunikasi dan Ketrampilan Berkomunikasi dalam Keluarga; Hakekat Perkawinan menurut Kitab Hukum Kanonik 1983; Teologi Sakramen Perkawinan dan Moral Seksualitas. Komukasi dan Keterampilan Berkomunikasi Suami-Istri; Mengelola Konflik dalam Rumah Tangga.

e. Metode PMPET : Presentasi, Tanya-jawab; Diskusi, Drill, Simulasi.

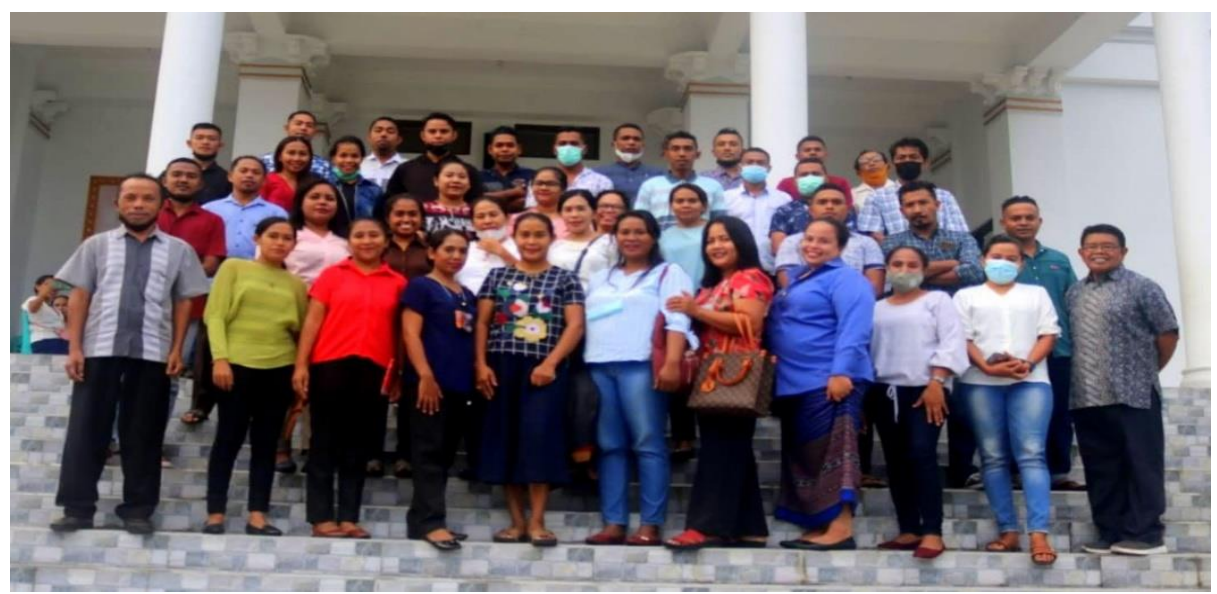

Gambar 1: Peserta PMPET di Paroki St. Yosef Onekore

\section{Hasil dan Pembahasan}

Berdasarkan asal usul paroki, calon pasangan peserta yang berasal dari Paroki Onekore sebanyak 28 orang (54\%). Yang berasal dari paroki-paroki lain sebanyak 24 orang (46\%).

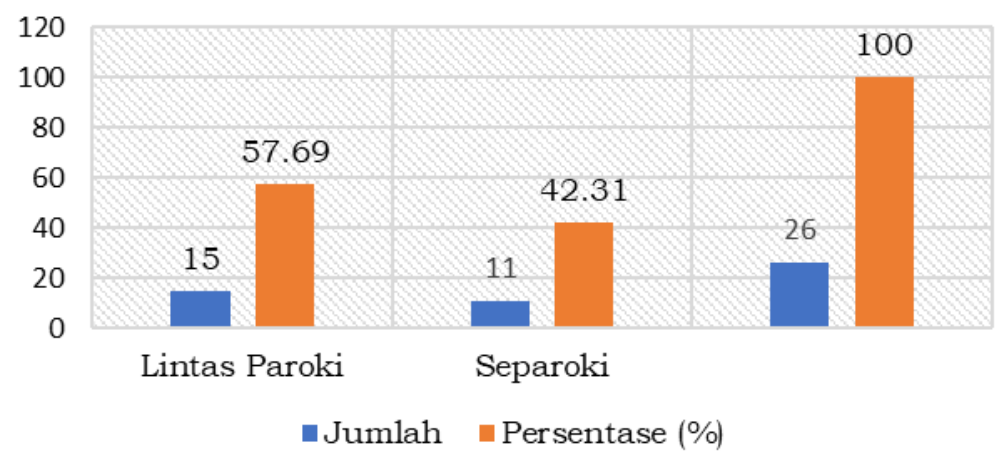

Gambar 2. Grafik asal paroki dan pemilihan pasangan 
Gambar 1 memperlihatkan bahwa mayoritas peserta pendidikan dan pelatihan persiapan perkawinan sebanyak 15 pasang atau 30 orang $(58 \%)$ memilih pasangannya dari wilayah paroki lain. Pemilihan pasangan pada kategori ini bercirikan pasangan perkawinan lintas batas paroki. Sisanya 11 pasang atau sebanyak 22 orang (42\%) memilih pasangannya dari paroki yang sama.

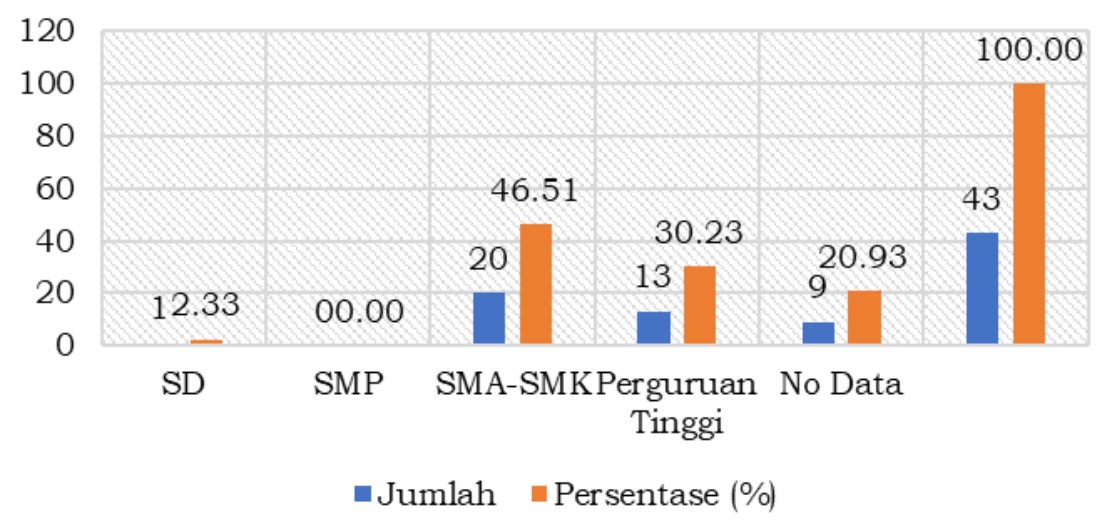

Gambar 3. Grafik Jenjang Pendidikan Peserta

Dari aspek jenjang pendidikan, peserta pendidikan dan pelahtihan persiapan perkawinan, memiliki latar belakang sebagai berikut. Peserta yang mengenyam pendidikan di Perguruan Tinggi sebanyak 13 orang (30,23\%). Pendidikan SMA/SMK (Sekolah Menengah Atas sebanyak 20 orang (46,51\%) Yang berpendidikan SMP 0 orang $(0 \%)$. Yang berpendidikan Sekolah Dasar sebanyak 1 orang $(0,33 \%)$. Sebanyak 9 orang $(20,93 \%)$ tidak memberi informasi tentang tingkat pendidikan mereka.

Di akhir kegiatan penyelenggaraan PMPET di Paroki St. Yosef Onekore, narasumber dari Universitas Flores coba menggali pengalaman belajar selama beberapa hari. Metode yang digunakan adalah tes akhir berupa angket yang dijawab oleh peserta. Tujuannya adalah untuk memperoleh gambaran dampak secara kuantitatif atas indikator-indikator yang dibahas selama PMPET. Perlu diingat bahwa konteks atau latarbelakang pendidikan peserta dijadikan rujukan utama untuk menggali pengalaman belajar dan selanjutnya merefleksikan data-data yang ada, apakah kegiatan PMPET sebagai sebuah model pendekatan persiapan perkawinan memiliki dampak terhadap intake (tingkat pemahaman) peserta untuk masing-masing indikator.

Dari 52 orang peserta yang dimintakan pendapatnya tentang indikatorindikator yang dibahas hanya 43 orang yang mempresentasikan sikap dan pendapatnya. Sisanya tidak mengembalikan angket. Dengan kata lain sebanyak 9 orang belum mau mengemukakan pendapatnya tanpa alasan. Namun dari sudut pandang pendekatan dan metode statistikal kuantitif 43 responden sudah sangat representatif untuk memberikan gambaran umum sesuai tujuan yang mau dicapai. Berikut ini adalah kesan umum peserta tentang PMPET. 


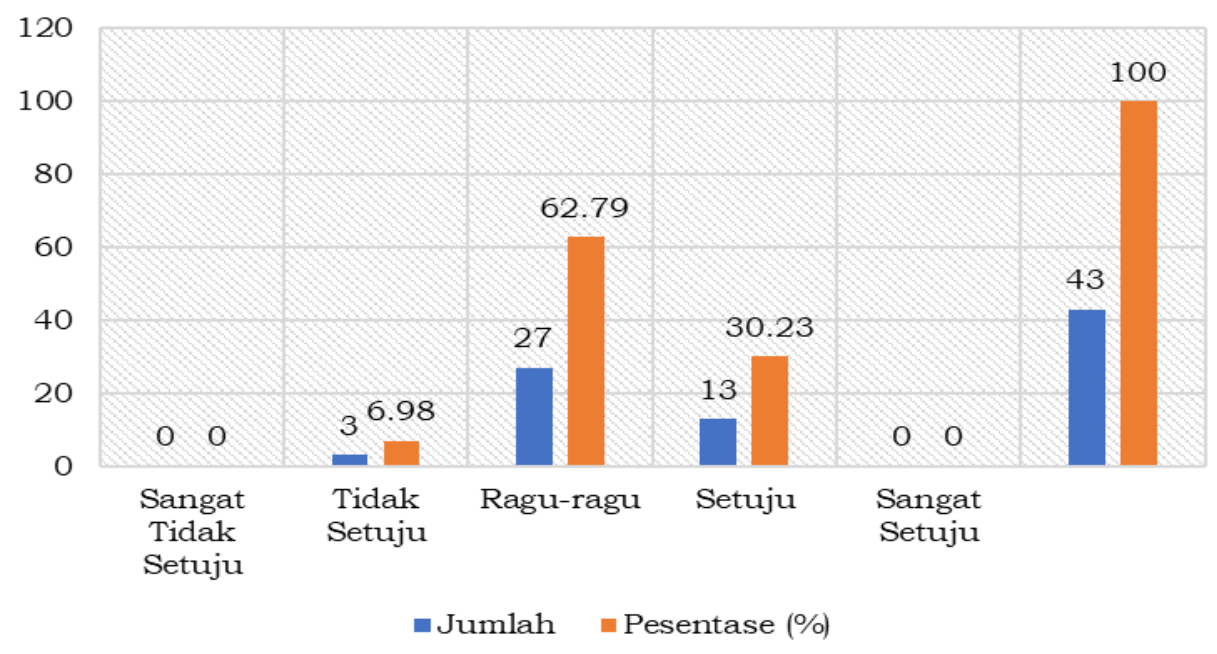

Gambar 4. Grafik persepsi responden tentang efisiensi dan efektifitas PMPET

Efisiensi dan efektivitas berkaitan dengan penggunaan sumber daya untuk menghasilkan sasuatu yang diharapkan atau direncanakan, walaupun sumber dayanya terbatas. Suatu kegiatan bisa dikatakan efisien dan efektif jika prosesnya berjalan dengan baik, lebih cepat dan lebih murah (Imelda Rahma, 2021 https://www.fimela.com). Efisiensi dan efektivitas berkaitan dengan hubungan antara input sumber daya (biaya, tenaga, waktu, dan sarana-prasarana) dan output (hasil yang diperoleh) (Palmer \& Torgerson, 1999). Efisien dan efektif tidaknya PMPET sebagai pendekatan dan model pembinaan persiapan perkawinan akan tampak pada input presentasi tematema pokok PMPET dan dampaknya terhadap kadar pemahaman (output) dan/atau intake peserta selama proses kegiatan.

Persepsi responden pada Gambar 4, menunjukkan PMPET berdampak positif $(27,9 \%)$. Ini berarti PMPET berlangsung efisien dan efektif, baik input maupun outputnya. Sebagian besarnya $(67,4 \%)$ mengalami bahwa PMPET belum efisien dan efektif. Mereka ragu-ragu bahwa tema yang dipresentasikan (input) dimengerti dengan baik (output). Sebagian kecil $(4,7 \%)$ belum paham akan tema pembahasan. Kesan ini didukung dengan temuan terdahulu bahwa efisiensi PMPET perlu dievalusi dan diatur ulang (Carroll \& Doherty, 2003).

Apakah benar PMPET sebagai pendekatan dan model pembinaan serta semua sumber daya di belakangnya berpengaruh baik atau sebaliknya, presentasi hasil penelurusan peserta membuktikannya dalam presentasi berikut ini.

Bagaimana suasana rohani dalam kehidupan keluarga Kristen dibangun? Bahan bangunan rohani ada di tangan orang tua. Jika mereka memilik iman kepada Tuhan, dan jika Kristus menjadi teman mereka seharihari maka mereka akan berusaha memberikan contoh bahwa hidup perkawinan dan keluarga yang dilembagakan ini menjadi tempat di mana mereka bermitra dengan Tuhan dalam segala hal (Bertels, 1948). Iman yang ditumbuhkembangkan melalui pendidikan dan pembinaan-pemibanaan dan 
dihayati dalam kehidupan praktis akan membuat suami-istri setia dan menjaga keharmonisan perkawinan (Midun \& Jenia., 2014).

Maka perkawinan tidak hanya menjadi lembaga keluarga tetapi cara mengalami Allah dan membangun keintiman relasi di dalamnya (Lakatos \& Martos, 2019). Penelitian yang dilakukan oleh Rostami menemukan bahwa unsur kecerdasan spiritual antara wanita dan pria menjelaskan kepuasan pernikahan secara berbeda. Maka disarankan agar pendampingan keluarga dalam bentuk apapun mempertimbangkan peran keyakinan agama, pendidikan iman dan penghayatan doa sebagai faktor-faktor penting penguatan hidup perkawinan, tetapi juga sebagai penangkal timbulnya konflik perkawinan dan penyelesaiannya (Rostami \& Gol, 2014).

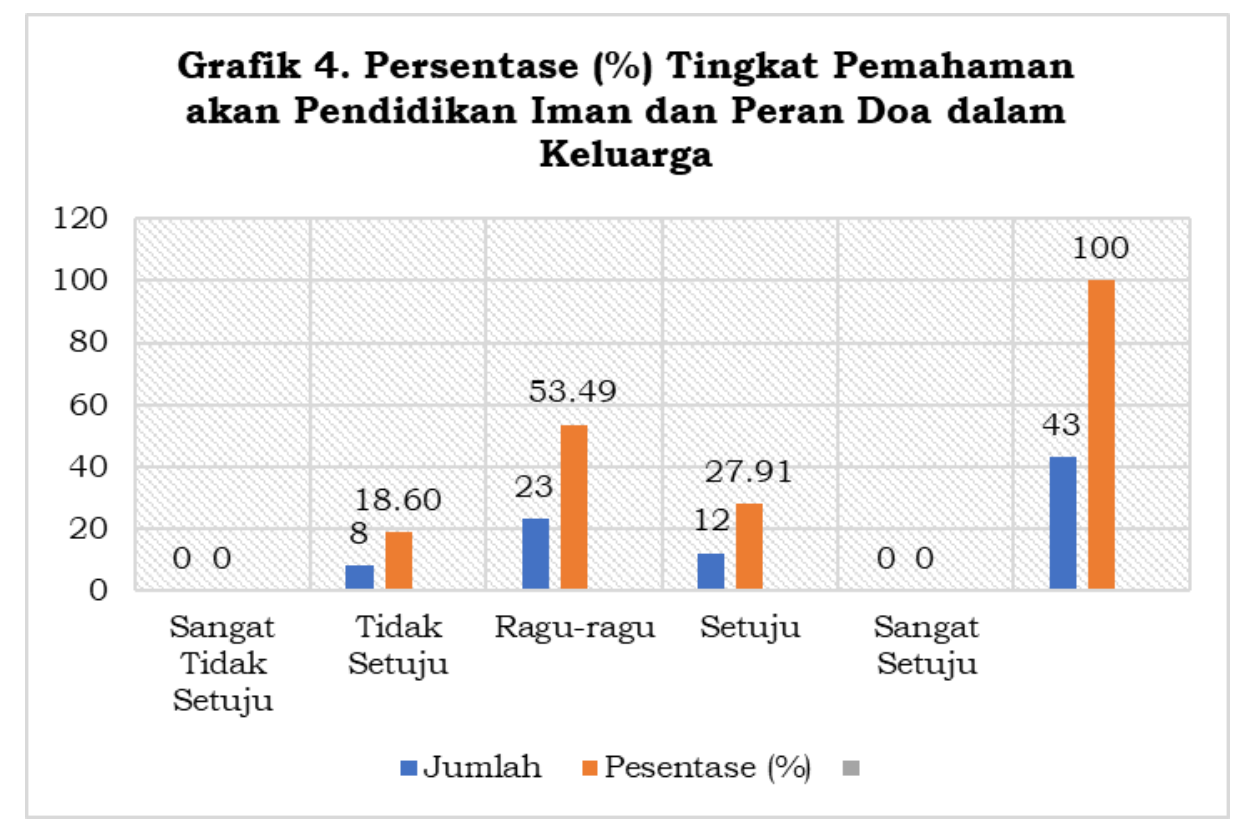

Gambar 5. Tingkat Pemahaman akan Pendidikan Iman dan Peran Doa

Gambar 5 menunjukkan bahwa hanya 12 orang responden $(27,91 \%)$ dari seluruh peserta yang berpartisipasi dalam penelusuran ini mehamami pentingnya pendidikan iman dan peranan doa dalam keluarga. Peserta yang ragu-ragu bahwa mereka memahami tema bahasan sebanyak 23 orang $(53,49 \%)$. Sebanyak 8 orang $(18,60 \%)$ tidak memaknai apa pun mengenai pentingnya pendidikan iman dan peran doa dalam keluarga sebagai salah dari pilar-pilar penopang ketahanan hidup perkawinan dan keluarga. Meskipun penelitian terdahulu mengatakan bahwa pendidikan iman dan peranan doa adalah hal penting yang perlu dibangun dan dikembangkan dalam perkawinan dan keluarga, namun dalam pelaksanaannya pokok ini mengalami pasang surut, dari aspek pengetahuan dan terutama minimnya upaya-upaya penghayatannya.

Kesehatan jasmani atau kesegaran jasmani adalah kemampuan tubuh untuk menyesuaikan fungsi alat-alat tubuhnya dalam batas fisiologi terhadap keadaan lingkungan dan atau kerja fisik yang cukup efisien tanpa lelah secara berlebihan. Kesehatan jasmani berhubungan dengan badan atau 
tubuh seseorang yang bebas dari segala macam dan jenis penyakit menurut standar ilmu kesehatan dan kedokteran. Kesehatan jasmani mempunyai fungsi yang penting dalam menjalani aktivitas sehari-hari. Semakin tinggi kesehatan jasmani seseorang, semakin meningkat daya tahan tubuhnya sehingga mampu untuk mengatasi beban kerja yang diberikan (Jamaludin Ancok, 2017). Pentingnya kesehatan jasmani bagi pasangan pra-nikah yang digarisbawahi dalam PMPET berkaitan dengan kesehatan reproduksi dan keluarga berencana sebagaimana yang ditekankan oleh Kementerian Kesehatan RI (Mulati Erna, 2021).

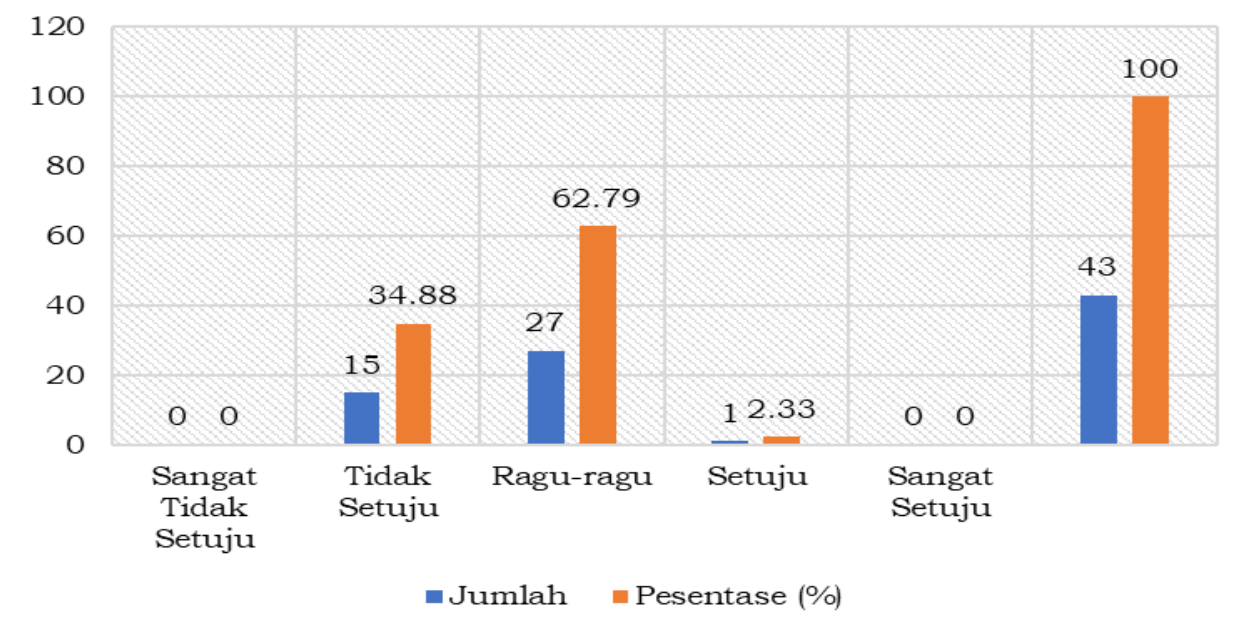

Gambar 6. Tingkat Pemahaman Akan Kesehatan Tubuh dan Keluarga Berencana

Pemahaman akan tema di atas digambarkan pada Grafik 5. Agak mengejutkan bahwa hanya 1 orang responden $(2,33 \%)$ yang mengerti akan tema tentang kesehatan tubuh dan keluarga berencana. Kebanyakan meragukan pemahaman mereka akan tema ini. Sebanyak 27 orang $(62,79 \%)$ berada di ranah ini. Dan sebanyak 15 orang $(34,88 \%)$ mengatakan tidak setuju kalau mereka paham akan tema ini.

Asosiasi Psikologi Amerika (APA) mengatakan kesehatan mental adalah keadaan pikiran yang dicirikan oleh kesejahteraan emosional, penyesuaian perilaku yang baik, kebebasan relatif dari kecemasan dan gejala yang melumpuhkan, dan kemampuan untuk membangun hubungan yang konstruktif dan mengatasi tuntutan dan tekanan hidup yang biasa (VandenBos, 2007). Kementerian Kesehatan RI, melalui Direktorat Promosi Kesehatan dan Pemberdayaan Masyarakat mengulas dan menjelaskan bahwa kesehatan mental yang baik adalah kondisi ketika batin seseorang berada dalam keadaan tentram dan tenang, sehingga memungkinkan dia untuk menikmati kehidupan sehari-hari dan menghargai orang lain di sekitar (Kemenkes RI, 2018, https://promkes.kemenkes.go.id). Seseorang yang bermental sehat dapat menggunakan kemampuan atau potensi dirinya secara maksimal dalam menghadapi tantangan hidup, serta menjalin hubungan positif dengan orang lain. Sebaliknya, orang yang kesehatan mentalnya terganggu akan mengalami gangguan suasana hati, kemampuan berpikir, serta kendali emosi yang pada akhirnya bisa mengarah pada perilaku buruk. 


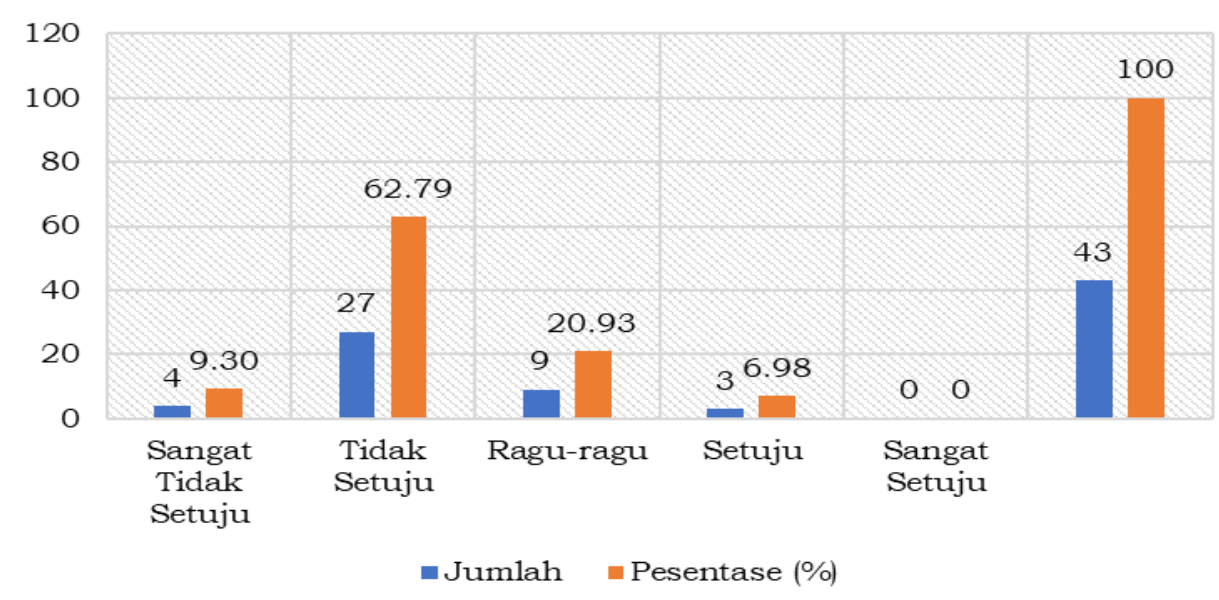

Gambar 7. Tingkat Pemahaman Akan Psikologi dan Kesehatan Mental

Gambar 7 memperlihatkan tingkat pemahaman responden akan tema psikologi dan kesehatan mental pria dan wanita. Ada 3 orang $(6,98 \%)$ yang mengatakan setuju kalau mereka paham akan tema ini. Yang meragukan pemahaman mereka sebanyak 9 orang $(20,93 \%)$. Yang tidak paham sebanyak 27 orang $(62,79 \%)$, dan yang sama sekali tidak paham sebanyak 4 orang $(9,30 \%)$. Bagi orang Katolik, perkawinan merupakan sesuatu yang suci. Dalam iman Katolik, sakramen merupakan tanda dan sarana kehadiran Tuhan yang menjadi sumber berkat dan keselamatan bagi umat-Nya. Perkawinan sakramental dalam Gereja Katolik, menekankan kesucian dari perkawinan yang nampak dalam diri pasangan suami-istri karena Allah hadir dalam diri mereka. Perkawinan lebih dari sekedar sebuah perjanjian kudus, seorang pria dan seorang wanita. Sesungguhnya perkawinan adalah sebuah institusi di mana disiplin rohani bertumbuh dan berkembang di dalamnya. Disiplin rohani yang dirancangbangun oleh Allah supaya pasangan sakramental mengenal Allah dengan lebih baik, dan mencintai-Nya lebih mendalam (Lon, 2019). Sebagai sakramen, perkawinan menjadi tanda rahmat bagi suami-istri untuk saling menguduskan (Reynolds, 2016).

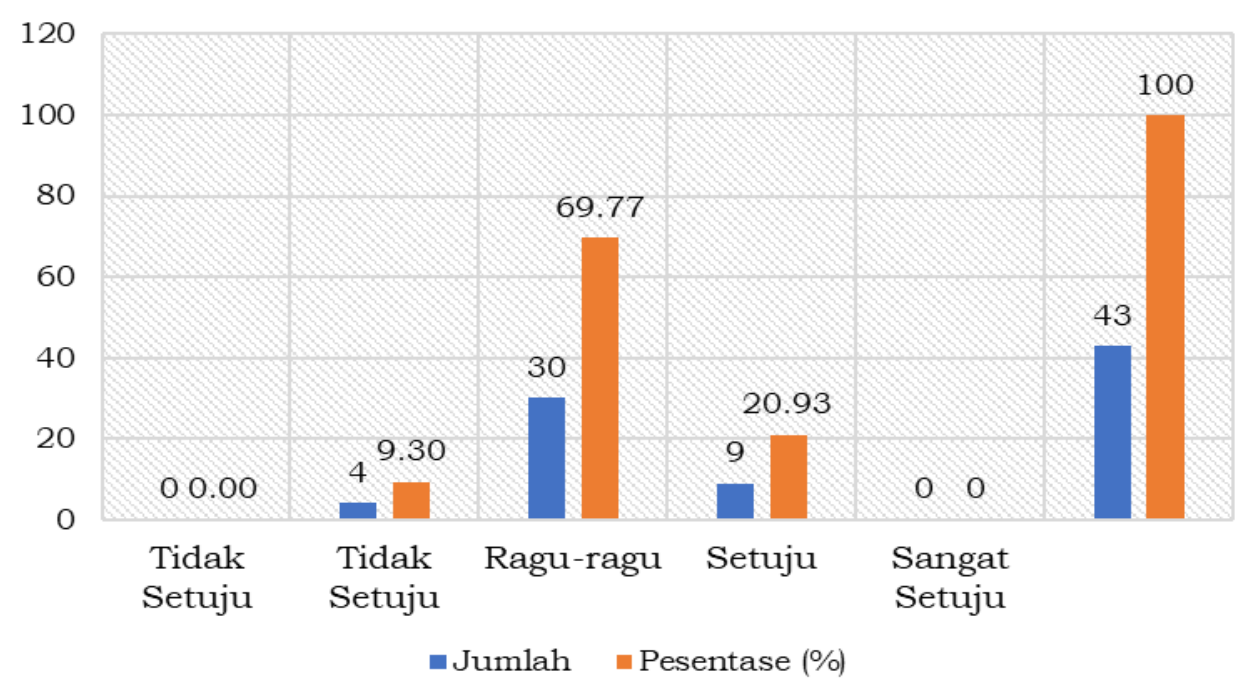

Gambar 8. Tingkat Pemahaman Akan Teologi Sakramen Perkawinan 
Dari 43 responden, 4 orang $(9,30 \%)$ mengatakan tidak setuju bahwa mereka mengerti ajaran Gereja tentang teologi Sakramen Perkawinan. 30 responden $(69,77 \%)$ mengatakan ragu-ragu kalau mereka paham akan tema ini. Kelompok ini berada pada posisi antara paham dan tidak paham. Sedang kelompok yang setujua bahwa mereka paham sebanyak 9 orang $(20.93 \%)$

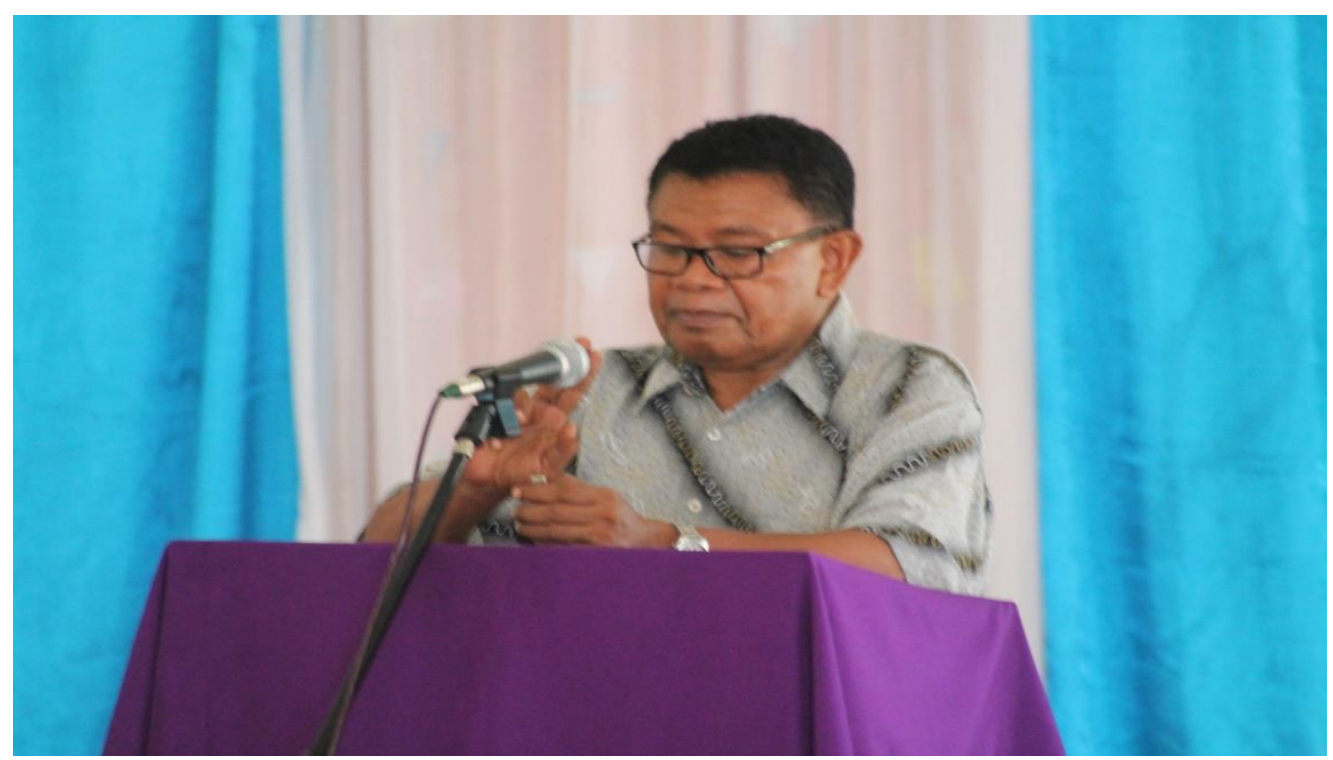

Gambar 9: Salah satu fasilitator

Kitab Hukum Kanonik (Kan. 1055), mengenai hakikat perkawinan, sungguh menekankan bahwa perkawinan dalam Gereja Katolik adalah perkawinan yang dilakukan antara sesama orang yang telah dibaptis. Perkawinan katolik berpegang teguh pada prinsip dan sifat perkawinan monogami, (Gobai et al., 2020) yang berarti bawha perkawinan itu dilakukan hanya oleh seorang laki-laki dan seorang perempuan. Karena sehakikat dan semartabat maka perkawinan hanya terjadi antara satu laki-laki dan satu perempuan sudah menjadi lengkap, utuh, sempurna, tak terceraikan, bebas dari halangan-halangan kanonik dan berlangsung seumur hidup dalam segala situasi dan kondisi. (Burke Cormac, 2015). 


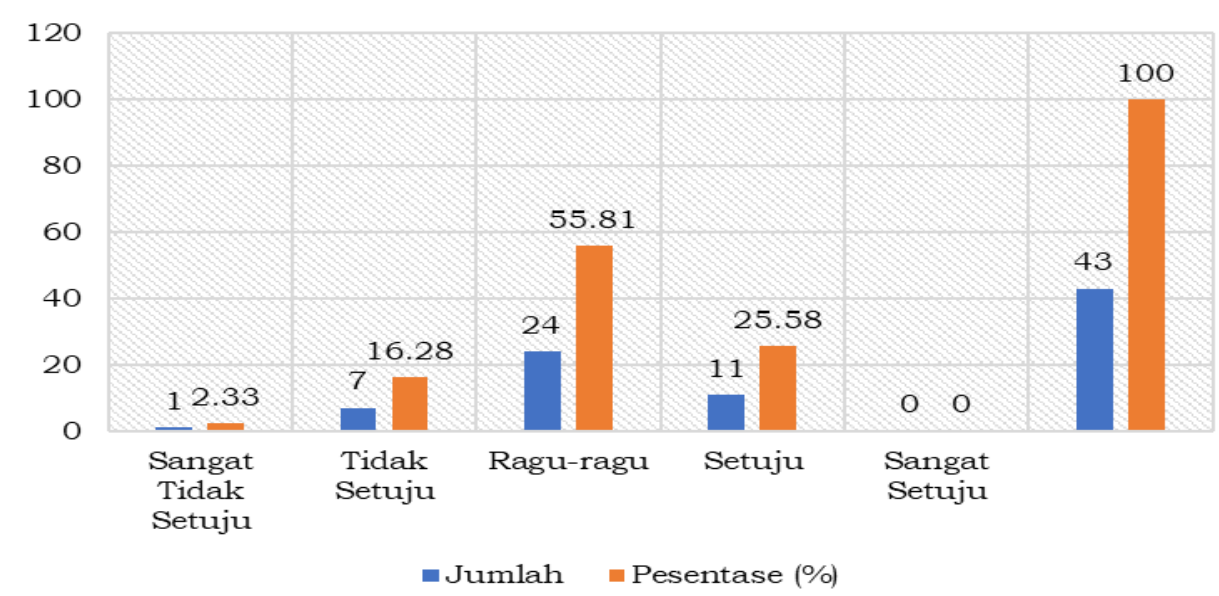

Gambar 10. Tingkat Pemahaman Akan Hukum Perkawinan Katolik

Tingkat pemahaman responden akan perkawinan menurut Hukum Gereja Katolik digambarkan dalam Gambar 10. Dari 43 responden 1 orang $(2,33 \%)$ mengatakan dia sama sekali tidak memahami tema perkawinan menurut hukum Gereja Katolik. Responden yang tidak setuju bahwa mereka paham akan tema ini sebanyak 7 orang $(16,28 \%)$. 24 orang responden (55,81\% ragu-ragu bahwa mereka paham. Sedangkan responden yang setuju bahwa mereka paham akan hakikat perkawinan menurut hukum Gereja Katolik sebanyak 11 orang $(25,58 \%)$.

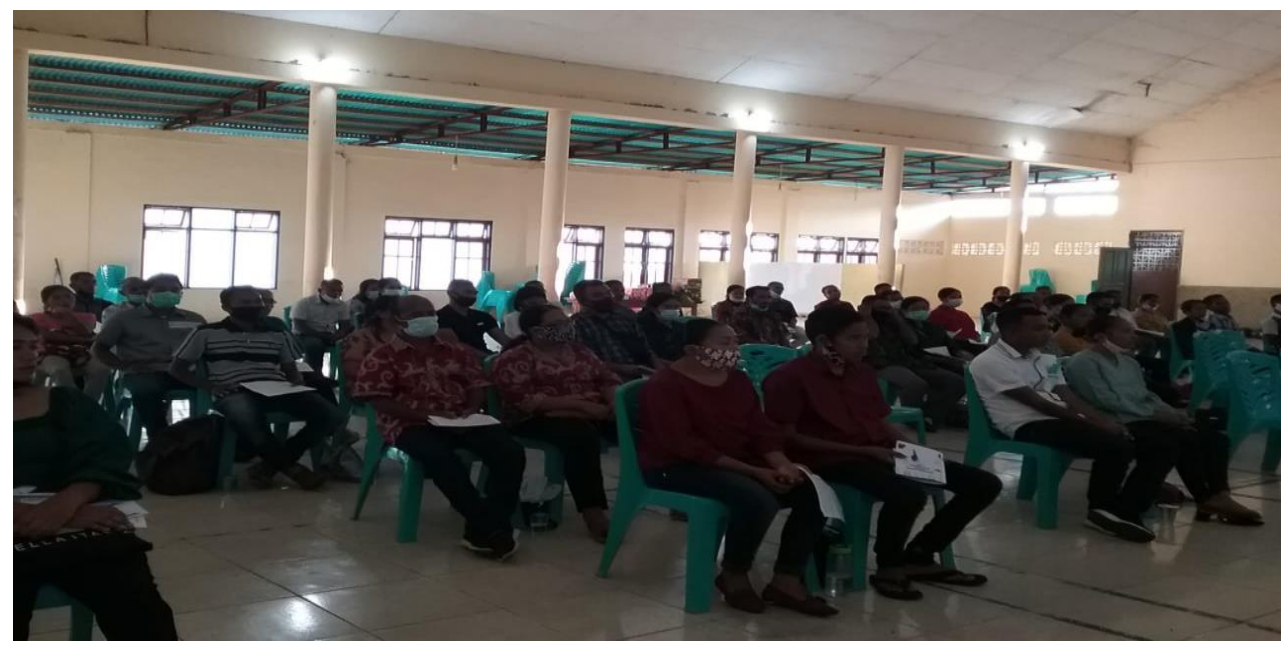

Gambar 11: Peserta PMPET di Paroki St. Yosef Onekore sedang mengikuti peamaran materi

Kesejahteraan ekonomi keluarga adalah sebuah kondisi kehidupan yang dicita-citakan oleh setiap keluarga pada umumnya, temasuk keluargakeluarga kristiaani (katolik). Kesejahteraan ekonomi keluarga mengacu pada status ekonomi keluarga yang memiliki sumber daya ekonomi yang memadai dan berkelanjutan sehingga keluarga dapat menjalani kehidupan yang nyaman secara ekonomis (Xiao, 2013). Maka manajemen ekonomi rumah tangga, adalah sebuah persoalan tersendiri yang perlu mendapat perhatian dan perlu dipahami dengan baik oleh calon-calon pasangan suami istri. 
Pengelolaan ekonomi rumah tangga yang baik, juga merupakan sebuah pilar, untuk kesejahteraan hidup keluarga. Kesejahteraan keluarga dari perspektif ekonomi bahkan akan memperkecil munculnya persoalan baru dalam hidup berumah tangga. Tetapi pengelolaan ekonomi rumah tangga yang baik perlu memperhatikan beberapa unsur indikator pendidikan, lapangan pekerjaan, pendapatan, pembelanjaan, jumlah anggota dalam keluarga, dan tanggungjawab sosial keluarga dalam kehidupan bermasyarakat (Hanum, 2018). Indikator-indikator ini pada akhirnya mengerucut pada bagaimana suami-istri mengelola keuangan keluarga (Kususiyanah, 2019) demi kesejahteran dan keharmonisan keluarga itu sendiri. Bagaimana konsep ini dipahami, grafik 12 menunjukkan hasilnya.

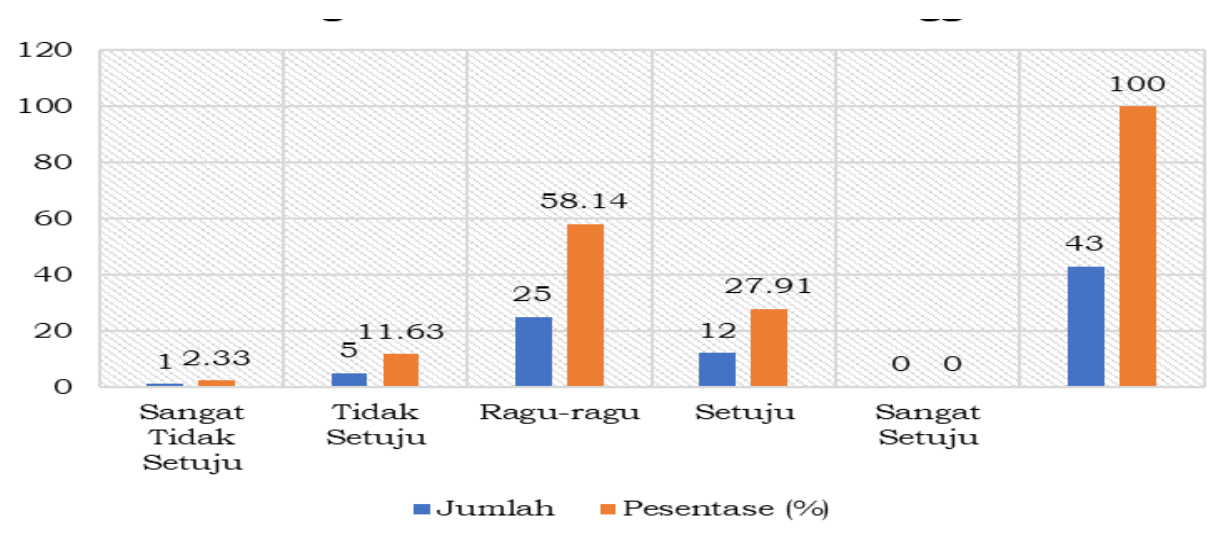

Gambar 12. Tingkat Pemahaman Akan Pengelolaan Ekonomi Rumah Tangga

Seorang responden $(2,33 \%)$ mengatakan sangat tidak setuju bahwa dia paham akan tema pengelolaan ekonomi rumah tangga. Kelompok berikutnya 5 responden $(11,63 \%)$ mengatakan tidak setuju bahwa mereka paham. Sebanyak 25 responden (58,14\%) ragu-ragu bahwa mereka paham. Responden yang paham akan tema bahasan pengelolaan ekonomi rumah tangga sebanyak 12 orang $(27,91 \%)$.

Teologi moral seksualitas dari sudut pandang Gereja Katolik, sama seperti pandangan teologi Katolik pada umumnya, bersumber dari hukum alam (hukum kodrat), kitab suci, hukum kanonik, wahyu ilahi, dan tradisi suci, sebagaimana yang ditafsirkan secara otoritatif oleh magisterium Gereja Katolik. Moralitas seksual mengevaluasi perilaku seksual berdasarkan standar yang ditetapkan oleh teologi moral Katolik, dan banyak menyajikan prinsip-prinsip umum yang melaluinya umat Katolik dapat mengevaluasi apakah suatu tindakan memenuhi standar tersebut. Banyak doktrin terperinci Gereja berpegang pada prinsip bahwa "kenikmatan seksual yang tidak teratur dan dicari demi kepentingan diri sendiri, serta dipisahkan dari tujuan prokreatif dan unitif perkawinan tidak dibenarkan dan tidak bisa dipertanggungjawabkan secara moral "(Stefanus Nay \& \& Ingrid Listiati, 2019, 14)

Dalam Humane Vitae, Paus Paulus VI mengatakan bahwa orang-orang yang menikah adalah kolaborator yang bebas dan bertanggung jawab dari Allah Sang Pencipta dalam transmisi "kehidupan manusia", sering kali terlepas dari kesulitan-kesulitan yang melekat. Karena itu seks dan 
penghayatannya harus menjunjung tinggi harkat dan martabat pria dan wanita, penggunaan alat-alat kontrasepsi untuk pengendalian kelahiran secara bertanggung jawab (Wagner William, 2009) (Spears \& Cheabu, 2014).

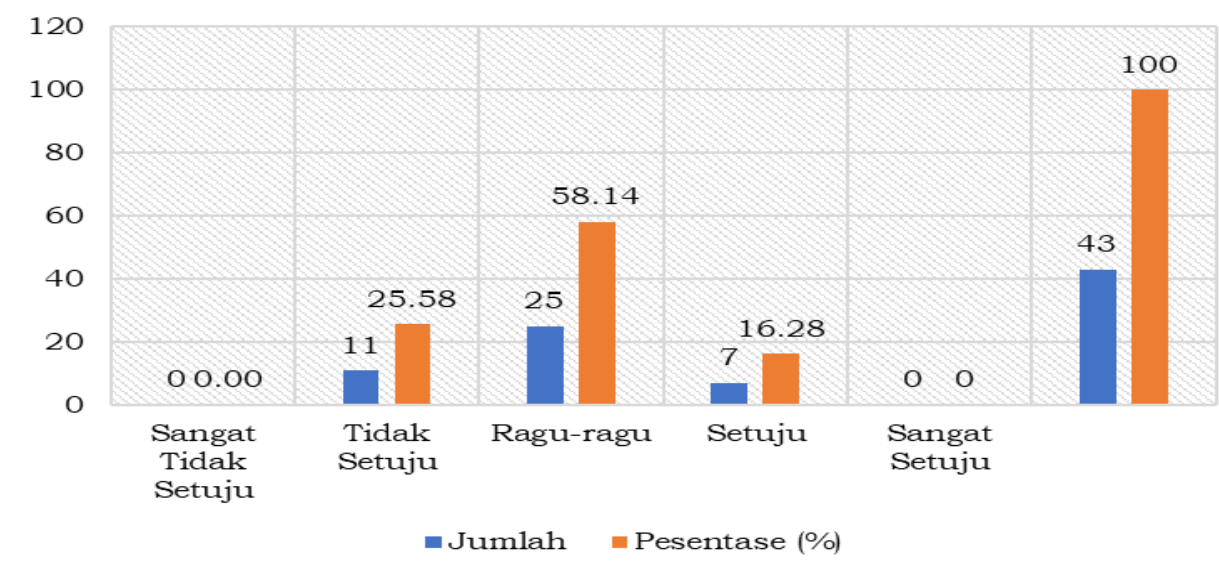

Gambar 13. Tingkat Pemahaman Akan Teologi Moral Seksualitas

Gagasan tentang Teologi Moral Seksualitas dipahami oleh 7 orang responden $(16,328 \%)$. Responden yang ragu-ragu bahwa mereka memahami tema ini sebanyak 25 orang $(58,14 \%)$. Dan responden yang tidak paham sebanyak 11 orang $(25,58 \%)$.

Komunikasi merupakan aktivitas dasar manusia. Komunikasi adalah "suatu proses ketika seseorang atau beberapa orang, kelompok, organisasi, dan masyarakat menciptakan, dan menggunakan informasi agar terhubung dengan lingkungan dan orang lain". Komunikasi adalah komponen terpenting dalam hidup kita, karena kita dipaksa untuk berkomunikasi, apa pun cara atau salurannya. Tidak diragukan lagi, di dunia kontemporer, komunikasi hadir dalam hubungan apa pun, dan proses komunikasi sangat penting. Kita semua sadar saat ini bahwa komunikasi yang sukses adalah dasar untuk kesuksesan pribadi atau profesional (Fraticiu \& Todericiu, 2013).

Di dalam berkomunikasi terjadilah proses penyampaian makna dari seseorang kepada orang lain, atau satu entitas kelompok ke kelompok lainnya melalui penggunaan tanda, simbol, dan aturan semiotika yang dipahami bersama. Pada umumnya, komunikasi dilakukan secara lisan atau verbal yang dapat dimengerti oleh kedua belah pihak. Kemampuan untuk berkomunikasi secara efektif dengan orang lain adalah keterampilan yang penting. Melalui komunikasi, orang mencapai pemahaman satu sama lain, belajar untuk menyukai satu sama lain, mempengaruhi satu sama lain, membangun kepercayaan, dan belajar lebih banyak tentang diri mereka sendiri dan bagaimana orang memahami mereka. Orang yang berkomunikasi secara efektif tahu bagaimana berinteraksi dengan orang lain secara fleksibel, terampil, dan bertanggung jawab, tetapi tanpa mengorbankan kebutuhan dan integritas mereka sendiri (Mantha Sharma \& Sivaramakrishna, 2001). Ini gagasan dasar tentang hakikat komunikasi dan penerapannya. Bagaimana ide ini dipahami oleh peserta PMPET grafik berikut menunjukkan hasilnya. 


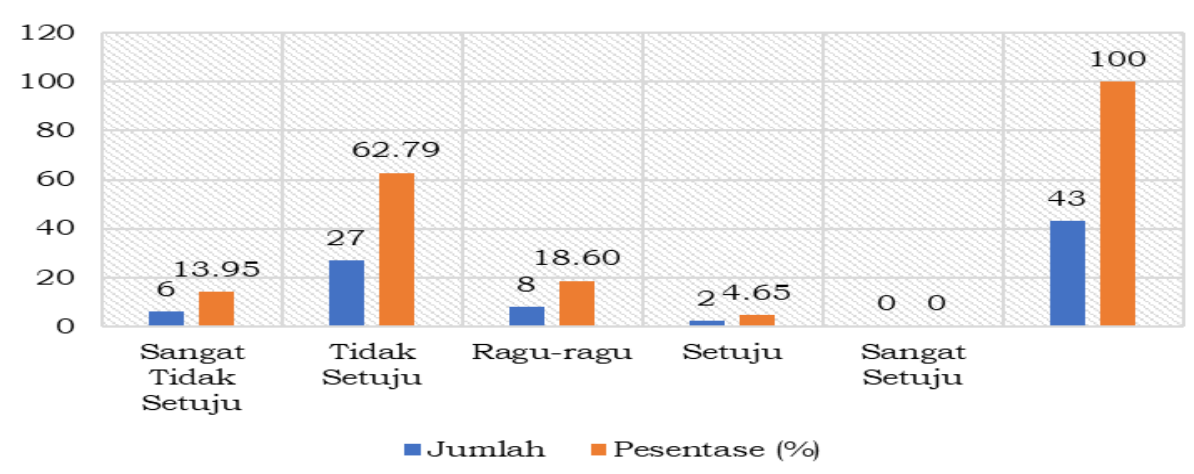

Gambar 14. Tingkat Pemahaman Akan Komunikasi dalam Rumah Tangga

Responden yang sangat tidak setuju bahwa mereka memahami tema komunikasi dan keterampilan berkomunikasi dalam keluarga sebanyak 6 orang $(13,95 \%)$. Responden yang tidak setuju bahwa mereka paham sebanyak 27 orang (62,79\%). Kelompok responden yang ragu-ragu bahwa mereka paham akan tema ini sebanyak 8 orang 1 (18,60\%. Dan kelompok responden yang paham akan tema ini sebanyak 2 orang $(4,65 \%)$.

Konflik adalah perjuangan yang dilakukan oleh berbagai pihak untuk memperoleh hal-hal yang langka seperti nilai, status, kekuasaan, otoritas, dan lain sebagainya, di mana tujuan dari mereka yang bertikai itu tidak hanya untuk memperoleh keuntungan, tetapi juga untuk menundukkan saingannya dengan kekerasan atau ancaman.

Panduan tentang penanganan konflik dari perspektif teori dan praktik mencatat bahwa konflik antara suami istri sering sulit diatasi karena konflik mereka bersifat destruktif atau merusak. Ini tercermin dari kecenderungan mereka untuk memicu perselisihan tentang hampir semua masalah tertentu, misalnya, pekerjaan rumah tangga, waktu tidur anak, menjadi perebutan kekuasaan di mana setiap pasangan merasa bahwa dirinya mandiri, harga diri atau identitas inti dipertaruhkan.

Proses destruktif inilah yang mengakibatkan saling curiga entah beralasan atau tidak berlasan; saling bermusuhan yang benar-benar dirasakan; orientasi menang-kalah; kecenderungan untuk menguasai yang lain; untuk menanggapi dengan cara mengkonfirmasi kecurigaan terburuk seseorang; ketidakmampuan untuk saling memahami; hilangnya rasa empati akan kebutuhan dan kerentanan orang lain; keengganan berbasis kesombongan, dendam yang terpendam, tersulut kemarahan apabila dihina dan merasa terhina, hilangnya kepekaan dan belaskasih dalam menanggapi tindakan yang positif pasangan. Ini semua menyebabkan suami-isteri tidak dapat keluar dari lingkaran setan konflik yang semakin meningkat di mana mereka berada.

Banyak pasangan dalam konflik seperti itu tidak mencari bantuan; mereka terus melecehkan satu sama lain, terkadang dengan kekerasan, atau mereka putus. Pasangan yang bekerja dengan saya mencari bantuan karena beberapa alasan. Di satu sisi, konflik mereka menjadi kekerasan fisik. Hal ini membuat mereka takut, dan juga bertentangan dengan nilai-nilai intelektual 
yang mereka pegang teguh mengenai kekerasan (Coleman et al., 2014). Grafik berikut menggambarkan tingkat pemahaman perserta akan gagasan tentang konflik dan bagaimana menanganinya.

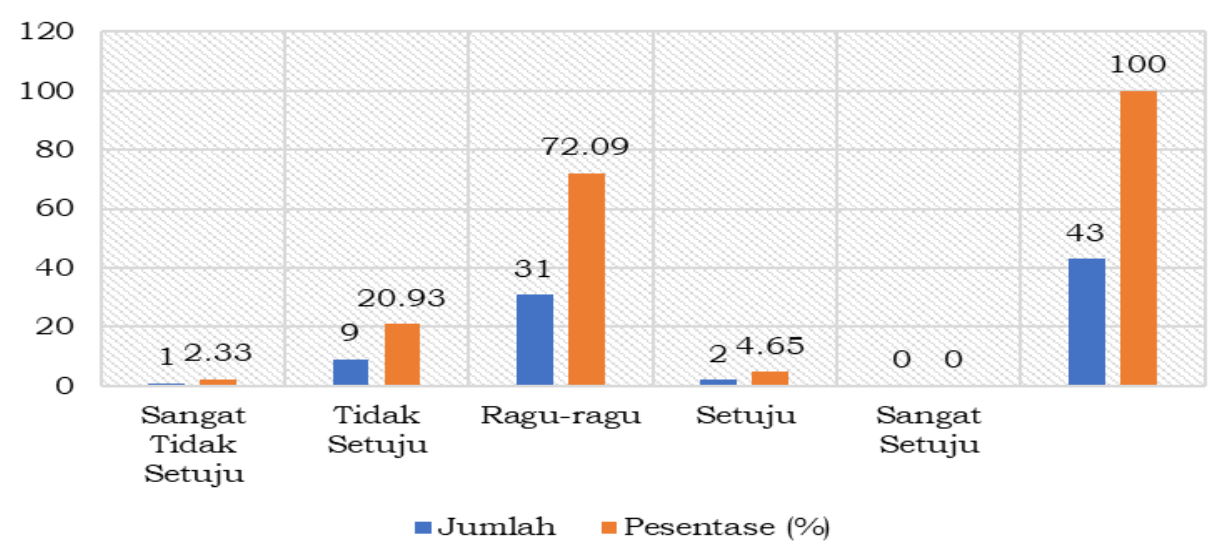

Gambar 15. Tingkat Pemahaman Akan Mengelola Konflik Rumah Tangga

Responden yang sangat tidak setuju bahwa dia memahami tema konflik dan mengelola konflik dalam rumah tangga 1 orang $(2,33 \%)$. Responden yang tidak setuju bahwa mereka paham sebanyak 9 orang $(20,93 \%)$. Sebanyak 31 orang responden $(72,09 \%)$ merasa ragu-ragu bahwa mereka paham. Dan yang setuju bahwa mereka paham sebanyak 2 orang responden $(4,65 \%)$.

Kesan umum peserta PMPET Paroki St. Yosef Onekore angkatan September 2021, akan efektif dan efisien atau tidaknya PMPET, digambarkan dalam grafik berikut sebagai rangkuman secara keseluruhan, dari skala sangat tidak setuju, setuju, ragu-ragu dan setuju untuk sembilan tema presentasi dan interpretasinya.

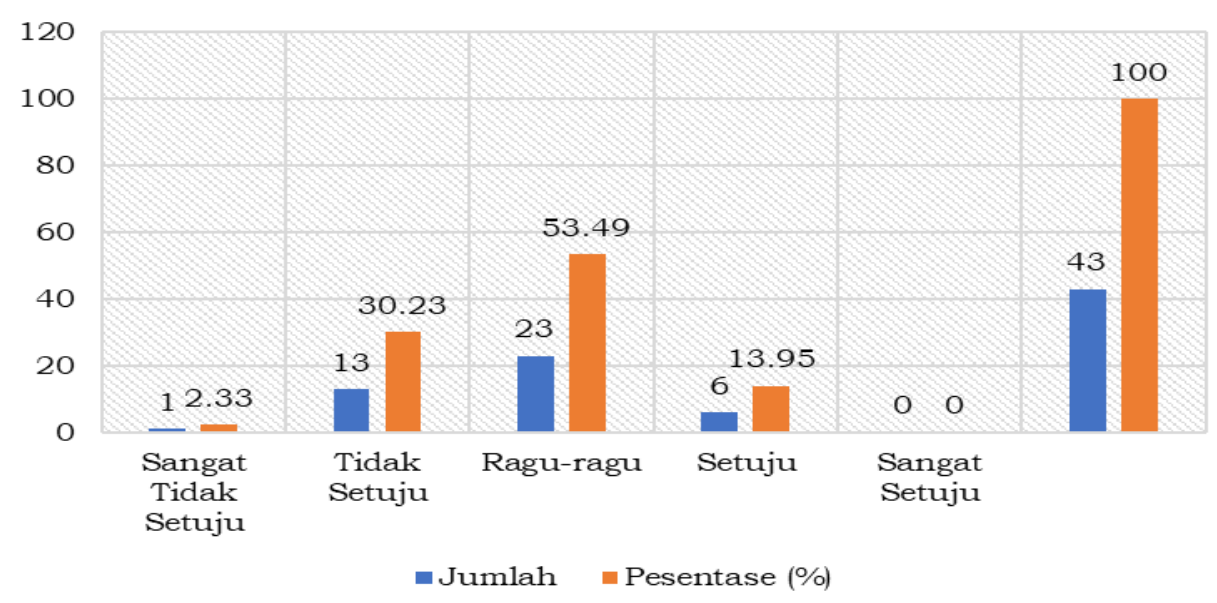

Gambar 16. Tingkat Pemahaman terhadap Semua Tema Bahasan

Secara keseluruhan 1 orang responden $(2,33 \%)$ mengatakan bahwa PMPEt sama sekali tidak berpengaruh untuk peningkatan pengetahuan, pemahaman, dan keterampilannya berkaitan dengan semua tema. Kelompok 
responden yang tidak setujua bahwa PMPET berpengaruh sebanyak 13 orang $(30,23 \%)$. Kelompok yang ragu-ragu entah PMPET sebagai pendekatan dan model pembinaan berpengaruh atau tidak, sebanyak 23 orang responden $(53,49 \%)$. Sedangkan kelompok responden yang mengalami PMPET sebagai pendekatan dan model pembinaan yang berpengaruh dalam meningkatkan pengetahuan, pemahaman dan keterampilan berkaitan dengan semua tema sebanyak 6 orang responden $(13,95 \%)$.

\section{Simpulan dan Tindak Lanjut}

Presentasi pendapat peserta PMPET secara grafis pada bagian hasil dan pembahasan memperlihatkan bahwa variabel independent efisiensi dan efektivitas PMPET tidak punya dampak yang signifikan terhadap kesembilan tema yang lain untuk dipahami dengan baik. Dari hasil analisa ini disimpulkan bahwa PMPET sangat insignifikan. Ini berarti PMPET tidak berpengaruh secara signifikan dalam meningkatkan pengetahuan, pemahaman dan ketrampilan mereka baik tentang tema-tema bahasan itu sendiri, maupun tentang hakikat dari sebuah perkawinan kristiani yang soroti dari beberapa sudut pandang.

Faktor-faktor penyebabnya antara lain karena, perbedaan latarbelakang berdasarkan faktor usia, faktor pendidikan, faktor waktu penyelenggaraan, faktor dukungan sarana, faktor kompetensi nara sumber, faktor disiplin. Halhal ini bisa dianggap sebagai faktor-faktor dominan yang berpengaruh terhadap intake (daya serap) peserta PMPET atas tema-tema yang dipresentasikan dan dijelaskan selama masa PMPET.

Berdasarkan penjelasan di atas maka disarankan agar PMPET dikelola ulang sekurang-kurangnya dari aspek durasi waktu penyelenggaraan, dan aspek pengkategorian level pendidikan peserta, dan peningkatan pengetahuan dan ketrampilan (TOT) para narasumber atau fasilitatores PMPET.

Berdasarkan penjelasan di atas, maka beberapa hal dapat direkomendasikan sebagai berikut. Pertama, dengan mengacu pada surat perjanjian kerja sama antara Pengurus Gereja dan Dana Papa Miskin Paroki St. Yosef Onekore sebagai pihak pertama dan PGSD Universitas Flores sebagai pihak kedua, maka tim fasilitator PGSD dapat mempresentasikan hasil temuan ini sebagai sebuah evaluasi dan refleksi, untuk membangun pemahaman bersama. Diharapkan agar kebijakan baru berkaitan dengan manajemen sumber daya dapat diberdayakan sedemikian rupa demi efisiensi dan efektivitas PMPET (Pendidikan dan Pelatihan Persiapan Perkawinan bagi pasangan calon suami istri). Kedua, dengan mempertimbangkan bahwa perjanjian kerja sama berlangsung multi year (selama 5 tahun pastoral) maka PGSD Universitas Flores terus berkomitmen untuk melaksanakan TOT (Training of Trainers) sebagai upaya penguatan kapasitas para fasilitator PMPET.

\section{Daftar Pustaka}

Bertels, M. I. (1948). Christian Education in the Family. https://digitalcommons. butler.edu/grtheses/345

Burke Cormac. (2015). The Theology of Marriage. The Catholic University of America Press.

Carroll, J. S., \& Doherty, W. J. (2003). Evaluating the Effectiveness of 
Premarital Education: A Review of Outcome Research. Family Relations, 52, 105-118.

Coleman, P. T. ., Deutsch, M. ., \& Marcus, E. C. . (2014). The Handbook of Conflict Resolution, Theory and Practice,. Jessy Boss, Wiley Brand.

Fraticiu, L., \& Todericiu, R. (2013). Efficient Organizational Communication. Europian Integration Realities and Perspectives, 186-190. https://www.researchgate.net/publication/320538014

Gobai, D. W., Korain, Y., Satu, Y., Tak, D., Daniel, T., Gobai, W., \& Korain, D. Y. (2020). Hukum Perkawinan Katolik dan Sifatnya - Sebuah Manifestasi Relasi Cinta Kristus kepada Gereja yang satu dan tak terpisahkan. Jurnal Hukum Magnum Opus Februari, 3(1).

Hanum, N. (2018). Analisis Kondisi Sosial Ekonomi Keluarga terhadap Kesejahteraan Keluarga di Gampong Karang Anyar Kota Langsa. Samudra Ekonomi Dan Bisnis, 9(1), 42-49.

Imelda Rahma. (2021). Efisiensi adalah Konsep Memaksimalkan Sumber Daya, Fimela. https://www.fimela.com

Jamaludin Ancok. (2017). MODUL PELATIHAN DASAR CALON PNS. Lembaga Administrasi Negara.

Kemenkes RI. (2018). Pengertian Kesehatan Mental. https:// promkes.kemenkes.go.id

Kususiyanah, A. (2019). Peran Suami Istri dalam Mengelola Keuangan Keluarga. Law of Family Studies, 1(2), 129-148.

Lakatos, C., \& Martos, T. (2019). The role of religiosity in intimate relationships. In European Journal of Mental Health (Vol. 14, Issue 2, pp. 260-279). Semmelweis University Institute of Mental Health. https://doi.org/ 10.5708/EJMH.14.2019.2.3

Lon, Y. S. (2019). HUKUM PERKAWINAN SAKRAMENTAL dalam GEREJA KATOLIK,. Penerbit Kanisius.

Mantha Sharma, S. \&, \& Sivaramakrishna, M. (2001). Handbook on Communicaiton Skills for Public Managers. Center for Good Governance.

Midun, H., Yuliana, \& Jenia, Y. (2014). Hubungan Penghayatan Iman Katolik dengan Nilai Kesetiaan Perkawinan Katolik. Jurnal Pendidikan Dan Kebudayaan Missio, 7(1), 142-149.

Mulati Erna, D. (2021). Buku Pedoman Konseling KB, Kementerian Kesehatan $R I$,.

Palmer, S., \& Torgerson, D. J. (1999). Definitions of efficiency. BMJ, 318(7191), 1136. https://doi.org/10.1136/bmj.318.7191.1136

Reynolds, P. L. 2016. (2016). How Marriage Became One of the Sacraments_ The Sacramental Theology of Marriage from its Medieval Origins to the Council of Trent. Cambridge University Press.

Rostami, A. M., \& Gol, H. C. (2014). Prediction of Marital Satisfaction based on Spiritual Intelligence. Procedia - Social and Behavioral Sciences, 116, 2573-2577. https://doi.org/10.1016/j.sbspro.2014.01.613

Spears, B., \& Cheabu, N. (2014). Humanae Vitae and Birth Control: Practices 
and Perspectives from the Ghanaian Catholic. Research on Humanities and Sciences, IV, No, 28., 49-59. https://www.researchgate.net/ publication/ 311924031

Stefanus Nay \&, \& Ingrid Listiati. (2019). Seks dan Perkawinan dalam hubungan dengan Magisterium Gereja. Katolisitas.Org. https://www.katolisitas.org

VandenBos, G. R. (Editor). (2007). APA Dictionary of Psychology (Second Edition).

Wagner William. (2009). Pope Paul VI Humane Vitae.

Xiao, J. J. (2013). Family economic well-being. In Handbook of Marriage and the Family: Third Edition (pp. 573-611). Springer US. https://doi.org/10.1007/978-1-4614-3987-5_24 